\title{
Oestrus and the vaginal smear cycle of the river otter, Lutra canadensis
}

\author{
G. B. Stenson* \\ Department of Zoology, University of British Columbia, Vancouver, British Columbia, \\ Canada V6T $2 A 9$
}

\begin{abstract}
Summary. Vaginal smears of river otters contained specific cellular associations which can be used to monitor their reproductive cycle. The anoestrous period was identified by the presence of large intermediate epithelial cells while the onset of pro-oestrus was gradual and the duration difficult to determine. Oestrus was indicated by an influx of nucleated and non-nucleated cornified cells which continue after mating. The metoestrous smear was characterized by large quantities of leucocytes and mucus.
\end{abstract}

Keywords: river otter; vaginal smears; oestrus; Lutra canadensis

\section{Introduction}

The use of vaginal smears is one of the simplest and most reliable methods of determining oestrus in live mammals. However, the pattern of vaginal development is species specific and often does not conform to the classic rodent cycle (D'Souza, 1978). Therefore, it is necessary to correlate vaginal smears with histological changes in the reproductive organs before the method can be reliably used. Among the mustelids, vaginal smears have been used successfully to identify the reproductive state of the ferret, Mustela putorius (Hamilton \& Gould, 1940), and the mink, Mutela vison (Hansson, 1947; Enders, 1952; Travis et al., 1978). This study provides a comparable investigation for the river otter, Lutra canadensis.

\section{Materials and Methods}

Five female river otters were live-trapped in southwestern British Columbia between February 1978 and September 1980, and held under natural environmental conditions for periods ranging from 8-42.5 months. Den boxes and pools with fresh, running water were provided in holding pens $(3.7 \times 3.7 \mathrm{~m})$ surrounded by chainlink fencing. Ages of 4 otters were determined by examination of dental cementum growth layers (Stephenson, 1977; Stenson, 1985) in tooth $\mathfrak{l}^{3}$. Ages ranged from 1 to 7 years at time of capture. The fifth female was classified as an adult based on body size.

Otters were examined under ketamine hydrochloride anaesthesia at $\mathbf{1}-2 \cdot$-week intervals. Vaginal smears were taken using a cotton swab inserted to a depth of $3-4 \mathrm{~mm}$, fixed in equal parts of $100 \%$ ethanol and ether, and stained with Schorr's stain. Cellular terminology is based on Wied (1958). However, the term 'cornified cell' was retained to be consistent with descriptions of other species. Cellular diameters were measured using an ocular micrometer. The relative importance of each cell type was determined by classifying all cells in 10 smears of each smear type. Individual variability was determined from daily smears from 2 females during the 1981 oestrous period.

The onset of oestrus was estimated to be mid-way between the date of the first fully cornified smear and the preceding sampling date. The end was similarly estimated between the dates of the last oestrous and first metoestrous smears.

One female was immature while 2 attained maturity during their second year in captivity. Six complete oestrous cycles were monitored in 4 adult females.

*Present address: Science Branch, Department of Fisheries and Oceans, P.O. Box 5667, St John's, Newfoundland, Canada AIC 5X1. 
Complete reproductive tracts of 11 wild or captive otters ( 2 anoestrous, 2 pro-oestrous, 1 oestrous, 1 metoestrous, 3 pregnant, 2 immature) were examined histologically to determine the relationship between vaginal histology and ovarian development. Vaginal smears were obtained from 5 of these females, a single adult in each of the four stages of the oestrous cycle and a pregnant female, immediately before removal of their reproductive tracts. Methods of collection, treatment of samples and a description of ovarian development are provided by Stenson (1985).

\section{Results}

The changes observed in the vaginal cytology are summarized in Table 1. All females underwent normal reproductive cycles in captivity and the ovaries, vaginae and vaginal smears of captive females were similar to those of wild otters at the same stage of ovarian development.

Table 1. Cell types present in the vaginal smears of river otters

\begin{tabular}{lcccc}
\hline \multirow{3}{*}{$\begin{array}{l}\text { Reproductive } \\
\text { state }\end{array}$} & \multicolumn{3}{c}{ Epithelial cells } \\
\cline { 2 - 4 } & Parabasal & Intermediate & Cornified & Leucocytes \\
\hline Anoestrus & ++ & +++ & & + \\
Pro-oestrus & + & +++ & + & + \\
Oestrus & + & + & +++ & + \\
Metoestrus & + & ++ & ++ & +++ \\
Pregnant & ++ & +++ & & + \\
Immature & +++ & ++ & & + \\
\hline
\end{tabular}

+ , few $(<10 \%) ;++$, moderate $(10-50 \%) ;+++$, many $(>50 \%)$.

The vaginal lumen of anoestrous adults was lined with 3-5 layers of cuboidal epithelium (Fig. 1a) which gave rise to the exfoliated epithelial cells typical of the anoestrous vaginal smear (Fig. 1c). Intermediate epithelial cells were the most common cell type identified and accounted for 56.6\% (range $=24 \cdot 5-79 \%$ ) of the cells present. They were large cells $(19-38 \mu \mathrm{m}$ ) with abundant, pale staining cytoplasm and round or oval nuclei. Parabasal cells, small $(8-15 \mu \mathrm{m})$, round, immature epithelial cells with little cytoplasm, were also common and comprised approximately $16 \%$ (range $=1 \cdot 5 \cdot 43 \cdot 5 \%$ ) of the cells present. Leucocytes and mucus were present throughout the anoestrous period but were usually scarce.

Changes between anoestrus and oestrus occurred slowly and no smear definitive of the prooestrous period could be identified. Intermediate cells increased in number during this period and were more angular in shape (Fig. 1d). Parabasal cells decreased in abundance and leucocytes became rare. The number of epithelial layers lining the vaginal lumen increased and cells were flattened. Late in pro-oestrus portions of the vaginal epithelium became cornified and most of the cells in the smears had a cornified, squamous appearance. Superficial cells, similar in appearance to intermediate cells but with pycnotic nuclei, occurred occasionally and the number of eosinophilic cells increased. As oestrus approached, squamous epithelial cells increased in number while other cell types declined.

During oestrus the vaginal epithelium consisted of 10-20 layers of flattened, cornified cells (Fig. 1b). The vaginal smear was dominated by large $(31-38 \mu \mathrm{m})$, angular cornified cells which comprised $90-100 \%$ of the cells present (Fig. 1e). The presence of nuclei in the cells varied greatly among different cycles. Although cornified cells with palely stained or pycnotic nuclei were common in early oestrus, non-nucleated cells were abundant in most females later in oestrus. Low numbers of leucocytes were also present in many smears during oestrus. The presence of leucocytes varied among smears, including those taken daily from individual females.

Large quantities of leucocytes, mucus and intermediate cells occurred during metoestrus (Fig. 1f). Leucocytes were the dominant cell type (mean $=70 \%$, range $=38 \cdot 5-83 \cdot 9 \%$ ) and the number 

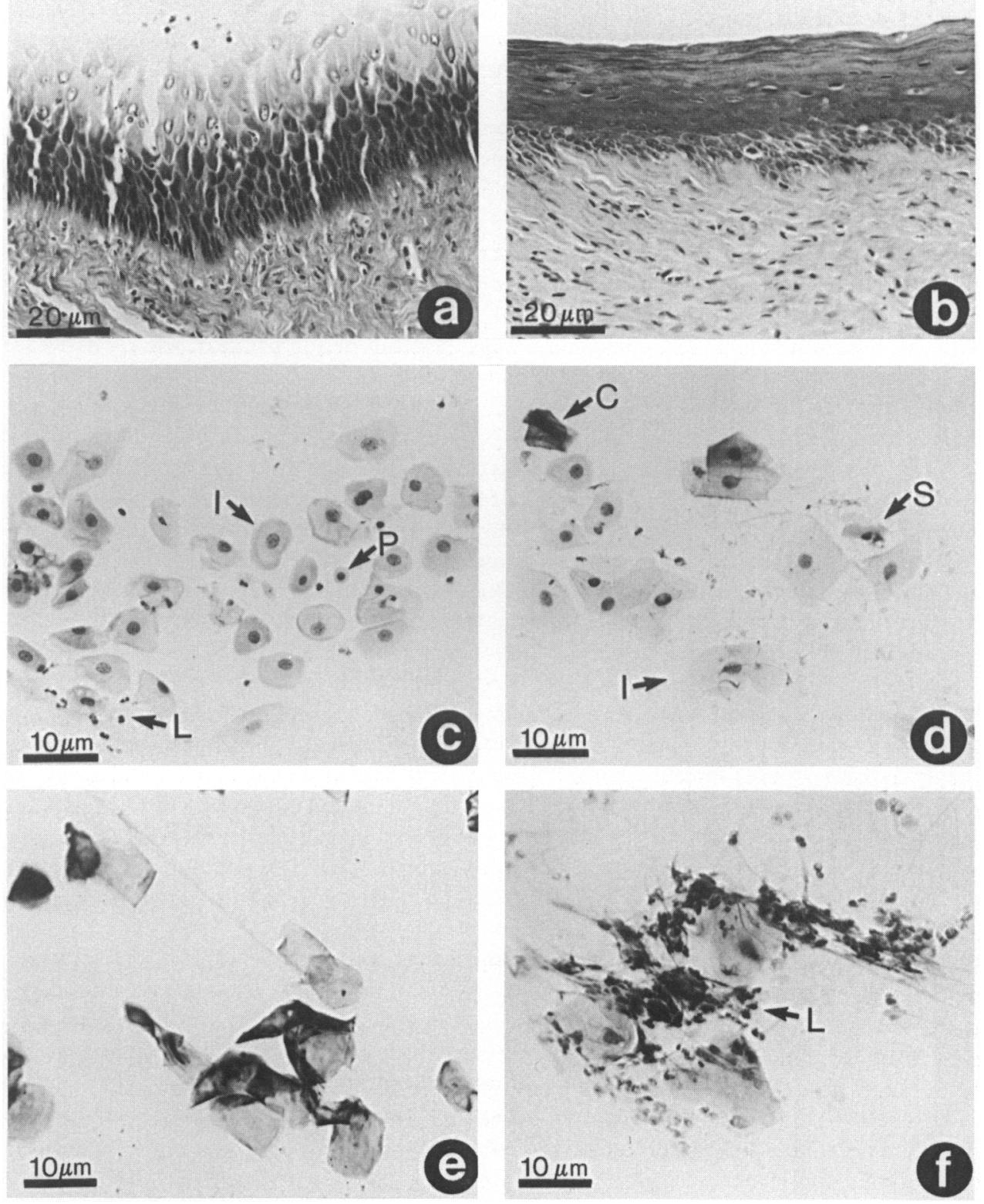

Fig. 1. Photomicrographs of the vagina and vaginal smears of river otters: $\times 400$. (a) Longitudinal section through the vagina of an anoestrous otter. (b) Longitudinal section through the vagina during oestrus. (c) A vaginal smear at anoestrus. Intermediate cells (I), parabasal cells (P) and occasional leucocytes (L) are present. (d) A vaginal smear at pro-oestrus containing intermediate cells (I), superficial cells (S), and the occasional cornified cells (C). Note the angular shape of many intermediate cells. (e) A vaginal smear at oestrus containing nucleated and non-nucleated cornified epithelial cells. (f) A vaginal smear at metoestrus. Abundant leucocytes (L) and mucus strands present. 
of intermediate cells increased as the cornified cells decreased in abundance. The metoestrous period continued for 3-6 weeks after which the anoestrous-type smear reappeared.

If a female was mated the cornified vaginal epithelium was sloughed after 2-3 weeks and the epithelium appeared similar to that during anoestrus for the remainder of pregnancy. Similarly, after an initial period of cornified cells, vaginal smears of pregnant otters could not be distinguished from those of anoestrous females.

The ovaries of 5 females for which recent vaginal smears were available were examined to determine whether vaginal smear types accurately reflected the degree of ovarian activity present. Large Graafian follicles $(>2.0 \mathrm{~mm}$ ) were present only in the ovaries of the animal with the oestrous smear type, while large corpora atretica were found in the female classified as metoestrus. The ovaries of otters with anoestrous and pro-oestrous smears contained small $(250-600 \mu \mathrm{m})$ and moderate to large $(1.4-1.8 \mu \mathrm{m})$ follicles respectively. The pregnant female had an anoestrous smear type.

Three of the adult females examined had a single oestrous period per year, while 1 had a second period of oestrus in each of the 3 years she was monitored. Based on the 6 cycles observed, the duration of the first (or only) oestrous period averaged $6 \cdot 2 \pm 0 \cdot 5$ (s.d.) weeks (range $=5-8$ weeks). When a second oestrus occurred, it followed a 2-3-week period of metoestrus and lasted for 3-5 weeks. The second oestrous period was characterized by vaginal smears containing a greater number of leucocytes than smears of the first or single oestrus. Oestrus generally began between late February and mid-March and ended between mid-April and mid-May.

Attempted matings of 2 females were observed, both occurring when the female involved had vaginal smears containing cornified cells only. One female who had two oestrous periods per year was mounted during both periods but not during the intervening metoestrous period.

The vaginae of immature otters were undeveloped and appeared similar to those of anoestrous adults. Vaginal smears were scanty and consisted primarily of parabasal $(62.8 \%$, range $=32 \cdot 6-$ $85 \cdot 2 \%)$ and intermediate epithelial $(23 \cdot 3 \%$, range $=12 \cdot 0-48 \cdot 9 \%)$ cells. Of the 3 immature females examined at 2 years of age, changes were observed in the smears of 2 during the breeding season. The vaginal smears of both females changed from those typical of immature animals to ones similar to adults during pro-oestrus. Intermediate cells were abundant and cornified cells were occasionally present. A full oestrous smear was not observed. Following the period of a modified smear, termed 'partial oestrus', the females had typical immature type smears. The periods of 'partial oestrus' lasted 7 and 3 weeks respectively in the 2 animals and occurred while accompanying adults were in oestrus.

Swelling of the vulva and the presence of mucus or blood in the vaginal smears were also monitored. All 3 were found to be loosely correlated with the annual cycle but were considered too variable to be used reliably as indicators of oestrus. Vaginal smears were usually dry during anoestrus and moist during oestrus or metoestrus but the amount of mucus present during oestrus varied greatly and smears containing large amounts of mucus occurred throughout the cycle. The appearance of blood in the vagina was also not confined to oestrus. The vulva was usually enlarged during oestrus but the degree and duration of the swelling varied greatly.

\section{Discussion}

Vaginal smears were considered to be successful indicators of the annual cycle of reproductive activity in the river otter. Captive females underwent cyclical changes in the cellular associations present which correlated with the annual reproductive cycle of British Columbian otters (Stenson, 1985). Also, the degree of ovarian development was correctly inferred by the condition of the vaginal epithelium and vaginal smears in females in which entire reproductive tracts were examined.

As in other mustelids (Hamilton \& Gould, 1940; Hansson, 1947; Enders, 1952; Mead, 1968), the anoestrous and oestrous periods could be clearly identified on the basis of the characteristic smears 
present but the changes which occurred during pro-oestrus were gradual and the duration was difficult to determine. The presence of vaginal smears dominated by cornified cells appears to be a good indicator of oestrus in the otter. Graafian follicles were only observed in the ovary of the female which had a vaginal smear with cornified cells or in wild females with cornified vaginae. Also, attempted matings occurred when females had cornified oestrous smears. Finally, the timing of oestrus, as determined by the presence of cornified cells, was similar to that seen among wild otters. Captive females exhibited oestrus between late February and mid-May while wild otters usually mate following birth in April or early May in British Columbia (Stenson, 1985). The captive females may have began oestrus earlier because they were not pregnant the previous year.

Other indicators of oestrus such as blood, mucus or degree of swelling were considered to be unreliable in the otter although they have been used previously (Liers, 1951) and vulvar swelling indicates oestrus in the mink (Travis et al., 1978). The presence of blood and mucus in the vulva and vaginal smear varied greatly in the otter and may have been affected by stress. Females were confined to a squeeze-type capture box before being anaesthetized and the amount of mucus and blood present appeared to be greater when difficulties were encountered capturing the animal.

Most otters exhibited a single prolonged oestrous period. One captive otter did exhibit two oestrous periods per year, however, suggesting that a second, shorter period may occur in some females if mating does not occur. A second oestrus has also been observed in monoestrous, induced ovulators such as the harbour seal, Phoca vitulina (Bigg, 1973) and may represent a subsequent wave of follicular development (Nalbandov, 1976). The length of the first oestrous period, identified by a cornified vaginal smear, varied from 5 to 8 weeks and averaged approximately 42 days. This is comparable to the observations of Liers (1951) who reported a single oestrous period of 4246 days in captive river otters, based on vaginal swelling and behaviour, with maximum receptivity every 6 days.

Although oestrus occurs during the period when cornified cells are present in the vaginal smear, it may end before the first metoestrous smear occurs. As in other mustelids (Hamilton \& Gould, 1940; Hansson, 1947; Smith, 1974), after mating there is an influx of cornified cells into the vaginal smear of otters which remained during the early stages of pregnancy. Also, cornified cells were present in vaginal smears taken after the ovaries and uteri were removed from an oestrous female.

The 'partial oestrus' observed in 2 immature otters suggests that an increase in oestrogen concentrations associated with follicular development had occurred. However, it is unknown if the degree of development was sufficient for ovulation. Wright (1966) found that while the reproductive organs of juvenile American badgers all showed marked stimulation during the breeding season, only a minority would mate and conceive. Alternatively, the otters may have ovulated without complete vaginal cornification, as seen in some cats (D'Souza, 1978). Sexual maturity is attained in some wild otters of the same age (Stenson, 1985) and the reduced degree of vaginal cornification may be associated with the first breeding season.

The prolonged oestrus and irregular pattern of vaginal smears observed in adult otters are characteristic of induced ovulators (Enders, 1953; MacFarlane \& Taylor, 1982). River otters have been suspected of being induced ovulators previously (Mead \& Wright, 1983) although no direct evidence is available. The lack of corpora lutea or corpora albicantia in the ovaries of captive females which had undergone oestrus (based on vaginal smears and behaviour) but were not mated supports this idea. Instead, only non-luteal corpora atretica were present, indicating that ovulation had not occurred. Also, progesterone concentrations remained low in unmated females which had exhibited cornified vaginal smears (Stenson, 1985). Although this evidence is circumstantial, it strongly supports the contention that otters are induced ovulators. Such a reproductive strategy would be advantageous in allowing otters, who are solitary animals (Melquist and Hornocker, 1983), to be receptive until located by a male and for ovulations to occur only when mated.

I thank H. D. Fisher for support and advice during this project, and L. V. Moore and E. Perry for reviewing this manuscript. This study was supported by a Natural Sciences and Engineering 
Research Council grant to H. D. Fisher and by National Research Council, Canadian Wildlife Service, and University of British Columbia Scholarships to G.B.S.

\section{References}

Bigg, M.A. (1973) Adaptations in the breeding of the harbour seal, Phoca vitulina. J. Reprod. Fert., Suppl. $19,131-142$.

D'Souza, F. (1978) The detection of oestrus. Symp. zool. Soc. Lond. 43, 175-193.

Enders, R.K. (1952) Reproduction in the mink (Mustela vison). Proc. Am. Phil. Soc. 96, 691-755.

Hamilton, W.J. \& Gould, J.H. (1940) The normal oestrus cycle of the ferret: the correlation of the vaginal smear and the histology of the genital tract, with notes on the distribution of glycogen, the incidence of growth, and the reaction to intra vitam staining by trypan blue. Trans. Roy. Soc. Edinb. 60, 87-109.

Hansson, A. (1947) The physiology of reproduction in mink (Mustela vison) with special reference to delayed implantation. Acta zool. 28, 1-136.

Liers, E.E. (1951) My friends the land otter. Natural History 60, 320.

MacFarlane, J.D. \& Taylor, J.M. (1982) Nature of estrus and ovulation in Microtus townsendii (Bachman). J. Mammal. 63, 104-109.

Mead, R.A. (1968) Reproduction in eastern forms of the spotted skunk (genus Spilogale). J. Zool., Lond. 156, 119-136.

Mead, R.A. \& Wright, P.L. (1983) Reproductive cycles of Mustelidae. Acta zool. fenn. 174, 169-172.
Melquist, W.E. \& Hornocker, M.G. (1983) Ecology of river otters in west central Idaho. Wildl. Monogr. 83, $1-60$.

Nalbandov, A.V. (1976) Reproductive Physiology of Mammals and Birds. W. H. Freeman and Company, San Francisco.

Smith, J.W. (1974) Reproduction in the female striped skunk, Mephitis mephitis. M.Sc. Thesis, Cornell University.

Stenson, G.B. (1985) The reproductive cycle of the river otter, Lutra canadensis, in the marine environment of southwestern British Columbia. Ph.D. thesis, University of British Columbia, Vancouver, B.C.

Stephenson, A.B. (1977) Age determination and morphological variation of Ontario otters. Can. J. Zool. 55, $1577-1583$.

Travis, H.F., Pilbeam, T.E., Gardner, W.J. \& Cole, R.S. (1978) Relationship of vulvar swelling to estrus in mink. J. Anim. Sci. 46, 219-224.

Wied, G.L. (1958) Opinion poll on cytological definitions and terminology. Acta cytol. 2, 25-139.

Wright, P.L. (1966) Observation on the reproductive cycle of the American badger (Taxidea taxus). Symp. zool. Soc. Lond. 15, 27-46.

Received 10 September 1987 